\title{
Inhibition of Listeria monocytogenes in Camembert cheese made with a nisin-producing starter
}

\author{
S Maisnier-Patin 1, N Deschamps 1, SR Tatini 2, J Richard 1 \\ 1 INRA, Station de Recherches Laitières, 78350 Jouy-en-Josas, France; \\ 2 University of Minnesota, Department of Food Science and Nutrition, St Paul, MN, 55108, USA
}

(Received 21 November 1991; accepted 14 February 1992)

\begin{abstract}
Summary - Camembert cheeses were made at 3 different times with milk containing initially $10^{1}$, $10^{3}$ or $10^{5}$ Listeria monocytogenes $/ \mathrm{ml}$. A nisin-producing starter composed of a pair of isogenic protease positive and protease negative strains of Lactococcus lactis subsp lactis was used to inhibit $L$ monocytogenes. Nisin concentration in curd and in cheese paralleled the growth of lactococci. Maximum nisin concentration of $c a 700 \mathrm{lU} / \mathrm{g}$ was obtained in curd at $9 \mathrm{~h}$, then nisin concentrations decreased slowly during 9-24 $\mathrm{h}$ and dramatically during ripening. In the presence of nisin, the numbers of $L$ monocytogenes decreased rapidly from $6 \mathrm{~h}$ to $24 \mathrm{~h}$. This inhibitory effect continued until the end of the second week of ripening in the core of Camembert cheeses, leading to a reduction of $3.3 \mathrm{log}$ Listeria/g (average from 3 experiments) compared to the initial level in cheese milk. Thereafter, regrowth occurred in Camembert cheeses, sooner on the surface than in the interior. However, a difference of $2.4 \mathrm{log}$ CFU/g between numbers of Listeria in cheese made with $\mathrm{Nis}^{+}$and $\mathrm{Nis}^{-}$starter cultures was maintained throughout ripening (6 weeks). Nisin was particularly effective when milk contained $10^{1}$ or $10^{3} \mathrm{~L}$ monocytogenes $/ \mathrm{ml}$.
\end{abstract}

\section{Listeria monocytogenes / starter / inhibition / nisin / Camembert cheese}

Résumé - Inhibition de Listeria monocytogenes dans du Camembert fabriqué avec un levain producteur de nisine. Des Camemberts ont été fabriqués à 3 reprises avec du lait contenant $10^{1}$, $10^{3}$ ou $10^{5}$ Listeria monocytogenes $/ \mathrm{ml}$. Deux souches isogéniques, protéase positive et protéase négative, productrices de nisine appartenant à l'espèce Lactococcus lactis subsp lactis ont été utilisées afin d'inhiber $\mathrm{L}$ monocytogenes. L'évolution de la concentration en nisine, dans le caillé et les fromages était parallèle à l'évolution des lactocoques. La concentration maximale en nisine, environ $700 \mathrm{Ul} / \mathrm{g}$, était obtenue à $9 \mathrm{~h}$, puis elle diminuait progressivement de $9 \mathrm{~h}$ à $24 \mathrm{~h}$ et ensuite rapidement lors de l'affinage. En présence de nisine, le nombre de $\mathrm{L}$ monocytogenes diminuait rapidement de 6 à 24 h. L'effet inhibiteur se poursuivait à l'intérieur des fromages jusqu'à la deuxième semaine, conduisant à une réduction du nombre de Listeria de 3,3 log UFC/g (moyenne de 3 expériences) par rapport au nombre initial dans le lait. Puis, la croissance reprenait dans les fromages, plus précocement à la surface qu'à l'intérieur. Cependant, une différence de 2,4 log UFC/g entre les nombres de L monocytogenes dans les fromages fabriqués avec des levains Nis+ et Nis- était maintenue jusqu'à la fin de l'affinage (6 semaines). L'efficacité de la nisine était la plus importante quand le lait contenait $10^{1}$ ou $10^{3}$ Listeria $/ \mathrm{ml}$. 


\section{INTRODUCTION}

It is well known that Listeria monocytogenes, which is potentially pathogenic, has the ability to withstand a wide variety of environmental conditions. In particular, $L$ monocytogenes has been shown to survive the processing and storage of fermented milk and cheeses. Studies with cheeses made from artificially inoculated milk indicated that the behaviour (growth, survival or inhibition) of $L$ monocytogenes in these products depends mainly upon $\mathrm{pH}$ and temperature conditions during manufacture, ripening, and storage. During ripening of Cheddar and storage of Colby cheeses, the numbers of $L$ monocytogenes decreased gradually from 3.5 to 1.5 $\log \mathrm{CFU} / \mathrm{g}$, with a D-value of 58 days (Ryser and Marth, 1987a; Yousef and Marth, 1988), whereas in Blue cheese, after a slight increase during cheese making, the numbers dropped rapidly at the beginning of ripening and then stabilized (Papageorgiou and Marth, 1989). During Camembert manufacture, the numbers of $L$ monocytogenes increased 10 -fold, then decreased during the first 18 days of ripening and finally reinitiated growth as a consequence of a rise in pH (Ryser and Marth, 1987b).

Apart from the use of effective fermentation, a potential means of controlling pathogens in cheese is through antimicrobial compounds produced by lactic acid bacteria (Tagg et al, 1976; Klaenhammer, 1988; Spelhaug and Harlander, 1989; Schillinger, 1990). Nisin, a polypeptide antibiotic of 34 amino acids, is one of these compounds which has been studied the most (Hurst, 1981). Nisin-producing strains of Lactococcus lactis subsp lactis were first employed by Hirsch et al (1951) to inhibit gas-blowing by anaerobic sporeformers in Swiss-type cheese. Later, for the same purpose, Lipinska (1977) used nisin-producing strains in combination with nisin-resistant ones possessing desirable cheese making properties for the production of hard and semi-hard cheese. No further attention seems to have been paid to $\mathrm{Nis}^{+}$starters, probably because they did not have the required properties to make cheese (low rate of acidification, limited proteolytic activity, high sensitivity to phages, etc).

Recently, some authors (Mohamed et al, 1984; Benkerroum and Sandine, 1988; Asperger et al, 1989; Carminati et al, 1989; Harris et al, 1989) have revived interest in nisin by showing that this bacteriocin exerts a bactericidal effect towards $L$ monocytogenes in culture media as well as in some kinds of cheeses.

In the present study, a starter combining appropriate phenotypes, ie a lactosepositive, protease-positive $\left(\mathrm{Prt}^{+}\right)$, nisinproducing $\left(\mathrm{Nis}^{+}\right)$strain of Lactococcus lactis subsp lactis along with a proteasenegative (Prt) variant was successfully used to make cheese. The purpose of this preliminary study was to evaluate the potential of this $\mathrm{Nis}^{+}$starter to inhibit $L$ monocytogenes during Camembert cheese manufacture and ripening, and identify problems that might be encountered in making Camembert cheese with such a starter.

\section{MATERIALS AND METHODS}

\section{Strains and media}

\section{L monocytogenes}

One strain of $L$ monocytogenes V7 (milk isolate, serotype 1) was used. Stock cultures were maintained at $4{ }^{\circ} \mathrm{C}$ on Tryptic-Soy Agar (TSA, Difco) slants and transferred bimonthly. An intermediate active culture was prepared by transferring the stock culture into TSB (Tryptic-Soy Broth, Difco) and incubating for $18 \mathrm{~h}$ at $30{ }^{\circ} \mathrm{C}$. A working culture was prepared by inoculating reconstituted skim milk (ULN, Elle et Vire, France, 10\% total solids) with the intermediate culture. After 
$18 \mathrm{~h}$ at $30^{\circ} \mathrm{C}$, the milk culture was in stationary growth phase (ca $5 \times 10^{8} \mathrm{CFU} / \mathrm{ml}$ ). Appropriate dilutions of this culture were added to pasteurized milk in the cheese vats to obtain initial numbers of ca $10^{1}, 10^{3}$ or $10^{5}$ Listeria/ml.

\section{Starter cultures}

The strains of Lactococcus lactis subsp lactis were obtained from the collection of the Station de Recherches Laitières. L lactis subsp lactis CNRZ 1076, a nisin-negative (Nis ${ }^{-}$), proteasepositive $\left(\mathrm{Prt}^{+}\right)$strain and its protease-negative (Prt) variant CNRZ 1075 were selected as control strains along with $\mathrm{Nis}^{+}, \mathrm{Prt}^{+}$and $\mathrm{Nis}^{+}, \mathrm{Prt}$ strains of $L$ lactis subsp lactis (CNRZ 150). Active cultures of $\mathrm{Prt}^{+}$and $\mathrm{Prt}$ strains in skim milk were added to cheese milk to provide an inoculum of $2 \%\left(0.4 \% \mathrm{Prt}^{+}\right.$and $\left.1.6 \% \mathrm{Prt}\right)$ giving a total of $\mathrm{ca} 10^{7} \mathrm{CFU} / \mathrm{ml}$. This association of isogenic $\mathrm{Prt}^{+}$and $\mathrm{Prt}$ strains has been recommended to minimize bitterness in cheese (Vassal, personal communication) despite the fact that addition of $\mathrm{Prt}$ strain to one $\mathrm{Prt}^{+}$decreases the rate of milk acidification (Juillard, 1991).

\section{Cheese manufacture}

Camembert cheese was made in our pilot plant. Essential steps in the cheese making are outlined in table I. Pasteurized $\left(72^{\circ} \mathrm{C} / 15 \mathrm{~s}\right)$ partially skimmed milk (28 g MG/l) warmed to $31-34^{\circ} \mathrm{C}$, was placed in $40-1$ vats and inoculated with $L$

Table I. Main characteristics of Camembert cheese-making.

Principales caractéristiques des fabrications de Camembert.

\begin{tabular}{|c|c|c|c|c|c|c|c|}
\hline \multicolumn{2}{|l|}{ Fabrication step } & \multicolumn{2}{|c|}{ Trial 1} & \multicolumn{2}{|c|}{ Trial 2} & \multicolumn{2}{|c|}{ Trial 3} \\
\hline & & $\mathrm{Nis}^{-a}$ & $\mathrm{Nis}^{+b}$ & Nis & $\mathrm{Nis}^{+}$ & $\mathrm{Nis}^{-}$ & $\mathrm{Nis}^{+}$ \\
\hline $\begin{array}{l}\text { Milk inoculation } \\
\text { (pH 6.6-6.7) }\end{array}$ & $\begin{array}{l}t^{c} \\
T^{d}\end{array}$ & $\begin{array}{c}0 \\
30.8\end{array}$ & $\begin{array}{c}0 \\
30.8\end{array}$ & $\begin{array}{c}0 \\
33.8\end{array}$ & $\begin{array}{c}0 \\
33.9\end{array}$ & $\begin{array}{c}0 \\
33.0\end{array}$ & $\begin{array}{c}0 \\
33.0\end{array}$ \\
\hline $\begin{array}{l}\text { Cutting curd } \\
(\mathrm{pH} 6.0-6.1)\end{array}$ & $\begin{array}{l}\mathrm{t} \\
\mathrm{T}\end{array}$ & $\begin{array}{r}5.0 \\
28.4\end{array}$ & $\begin{array}{r}5.8 \\
27.4\end{array}$ & $\begin{array}{r}4.2 \\
29.9\end{array}$ & $\begin{array}{l}4.7 \\
29.6\end{array}$ & $\begin{array}{r}3.1 \\
31.1\end{array}$ & $\begin{array}{r}3.3 \\
31.0\end{array}$ \\
\hline $\begin{array}{l}\text { Dipping } \\
\text { (pH 5.6-5.8) }\end{array}$ & $\begin{array}{l}\mathrm{t} \\
\mathrm{T}\end{array}$ & $\begin{array}{r}5.3 \\
28.0\end{array}$ & $\begin{array}{r}6.2 \\
27.0\end{array}$ & $\begin{array}{r}4.8 \\
28.3\end{array}$ & $\begin{array}{r}5.4 \\
27.8\end{array}$ & $\begin{array}{r}3.5 \\
29.0\end{array}$ & $\begin{array}{r}4.2 \\
30.0\end{array}$ \\
\hline $\begin{array}{l}\text { 1st turn } \\
(\mathrm{pH} 4.9-5.0)\end{array}$ & $\begin{array}{l}\mathrm{t} \\
\mathrm{T}\end{array}$ & $\begin{array}{l}6.7^{\mathrm{e}} \\
26.8^{-}\end{array}$ & $\begin{array}{r}8.0 \\
25.7\end{array}$ & $\begin{array}{r}6.2 \\
27.6\end{array}$ & $\begin{array}{r}6.7 \\
27.2\end{array}$ & $\begin{array}{r}4.6 \\
29.1\end{array}$ & $\begin{array}{r}5.3 \\
29.1\end{array}$ \\
\hline $\begin{array}{l}\text { 2nd turn } \\
(\mathrm{pH} 4.6-4.8)\end{array}$ & $\begin{array}{l}\mathrm{t} \\
\mathrm{T}\end{array}$ & $\begin{array}{r}8.8 \\
25.5\end{array}$ & $\begin{array}{r}9.1 \\
25.3\end{array}$ & $\begin{array}{r}8.7 \\
26.5\end{array}$ & $\begin{array}{r}8.5 \\
26.4\end{array}$ & $\begin{array}{l}9.0 \\
25.6\end{array}$ & $\begin{array}{r}9.0 \\
25.7\end{array}$ \\
\hline $\begin{array}{l}\text { Salting } \\
\text { (pH 4.4-4.6) }\end{array}$ & $\begin{array}{l}\mathrm{t} \\
\mathrm{T}\end{array}$ & $\begin{array}{l}24.0 \\
19.0\end{array}$ & $\begin{array}{l}24.0 \\
19.0\end{array}$ & $\begin{array}{l}24.0 \\
19.0\end{array}$ & $\begin{array}{l}24.0 \\
19.0\end{array}$ & $\begin{array}{l}24.0 \\
22.5\end{array}$ & $\begin{array}{l}24.0 \\
22.2\end{array}$ \\
\hline
\end{tabular}

a Non nisin-producing lactic acid starter (Lactococcus lactis subsp lactis CNRZ 1076 (strain Prt+) and 1075 (strain Prt-); ${ }^{b}$ nisin-producing lactic acid starter (Lactococcus lactis subsp lactis CNRZ 150 (strain Prt ${ }^{+}$and Prt)); ${ }^{c}$ time (h); ${ }^{\mathrm{d}}$ temperature $\left({ }^{\circ} \mathrm{C}\right) ;{ }^{\mathrm{e}} \mathrm{pH}$ was 5.2 in this vat.

a Levain non producteur de nisine (Lactococcus lactis subsp lactis CNRZ 1076 (souche Prt') et 1075 (strain Prt); ${ }^{b}$ levain producteur de nisine (Lactococcus lactis subsp lactis CNRZ 150 (souches Prt+ et Prt); ${ }^{c}$ temps (h); ${ }^{d}$ température $\left({ }^{\circ} \mathrm{C}\right) ;{ }^{e}$ la valeur de $\mathrm{pH}$ dans cette bassine était 5.2 . 
monocytogenes, $2 \%$ lactic starter culture and spores of Penicillium camemberti. The clotting agent (rennet) was added at the same time. The coagulum was cut at $\mathrm{pH} 6.0$ and $20-50$ min lat$\mathrm{er}$, it was dipped into $12-\mathrm{cm}$ diameter hoops to allow the curd to drain. Hoops were turned twice, the first time when the $\mathrm{pH}$ was nearing 4.9-5.0, the second time when the $\mathrm{pH}$ was about 4.6-4.8. After draining overnight, cheese wheels were removed from hoops, dry-salted and stored at $11^{\circ} \mathrm{C}$ with $85-95 \%$ relative humidity up to the end of the ripening period. This relatively high temperature was chosen to accelerate ripening and to provide favorable conditions of survival and growth for Listeria.

\section{Experimental design}

Camembert cheeses were manufactured at 3 different dates. Each time, 2-5 vats were used. In the first experiment, 2 vats were used; 1 contained the $\mathrm{Nis}^{+}$and the other the Nis- starter. In both, milk was initially inoculated with $10^{5}$ Liste$\mathrm{ria} / \mathrm{ml}$. In the second experiment, the cheese milk of 1 vat was inoculated with the Nis ${ }^{-}$starter and $10^{1}$ Listeria/ml, 3 others were inoculated with the $\mathrm{Nis}^{+}$starter and $10^{1}, 10^{3}, 10^{5}$ Listeria/ml. The third experiment was the repetition of the second one, with 1 more vat which was inoculated with the Nis ${ }^{-}$starter and $10^{5}$ Listeria/ml.

Samples were taken from each batch during cheese manufacture (at time of inoculation and at $3,6,9,24 \mathrm{~h}$ ) and weekly during ripening up to the 6 th week. Milk and cheese were analyzed for numbers of viable $L$ monocytogenes and lactococci, $\mathrm{pH}$, and nisin concentration.

\section{Sample preparation}

Samples of milk ( $1 \mathrm{ml})$, curd $(1 \mathrm{~g})$ or cheese (3 portions of $3 \mathrm{~g}$ of core and crust taken separately from 3 wheels) were placed separately into sterile stomacher bags and diluted 1:10 with peptone water $(0.1 \%$ Difco). Samples were homogenized with the stomacher for $2 \mathrm{~min}$. Appropriate 10 -fold dilutions were spread on the surface of enumeration media using a spiral plater or a hockey stick if less than $10^{3}$ Listeria/ml were expected.

\section{Enumerations of bacteria}

\section{Listeria monocytogenes}

During the first experiment, 3 enumeration methods were compared: 1 relying on the use of selective agents, Oxford Agar incubated $48 \mathrm{~h}$ at $30^{\circ} \mathrm{C}$ (Curtis et al, 1989), and the others relying only on incubation under selective conditions: TSA-YE (Tryptic-Soy Agar plus $0.6 \%$ Yeast Extract, Difco), the plates being incubated for 22 days at $4{ }^{\circ} \mathrm{C}$ under anaerobic conditions (Gaspak System, $\mathrm{H}_{2}+\mathrm{CO}_{2}$ ), and BHIA (Brain Heart Infusion Agar, Difco) incubated for 28 days at $4^{\circ} \mathrm{C}$ in Raibaud's tubes (long narrow tubes insuring anaerobic conditions). Incubations were performed at low temperature and under anaerobic conditions, to prevent growth of the lactococci and molds, respectively. As the 3 methods gave similar counts (see Results and Discussion), Oxford Agar was the only medium used for the enumeration of $L$ monocytogenes in the subsequent experiments.

\section{Lactococci}

The enumeration of lactococci was performed on Fast Slow Differential Agar (FSDA, Huggins and Sandine, 1984). This medium gives the same lactococci numbers as M17 (Gratadoux, personal communication) and in addition allows differentiation of $\mathrm{Prt}^{+}$and $\mathrm{Prt}$ strains.

\section{Detection of Listeria}

When counts in cheese were expected to be less than $10^{1} \mathrm{CFU} / \mathrm{g}$, the procedure proposed by ISO (1989) for detection of $L$ monocytogenes in dairy products was used. A $25-\mathrm{g}$ sample, resulting from blending of 1 wedge from each of 3 cheeses, was mixed with $225 \mathrm{ml}$ of the Selective Enrichment Broth (SEB) using a Waring blender. This medium contained per I: $5 \mathrm{~g}$ of peptone from soy, $30 \mathrm{~g}$ of Tryptic Soy Broth, $6 \mathrm{~g}$ of yeast extract, $10 \mathrm{mg}$ of of acriflavin $\mathrm{HCl}, 40 \mathrm{mg}$ of nalidixic acid and 50 $\mathrm{mg}$ of cycloheximide. $L$ monocytogenes were detected after $48 \mathrm{~h}$ of enrichment at $30^{\circ} \mathrm{C}$, by streaking $0.1 \mathrm{ml}$ of SEB on Oxford Agar. The plates were incubated for $48 \mathrm{~h}$ at $37^{\circ} \mathrm{C}$. 


\section{Nisin determination}

The plate diffusion assay (Fowler et al, 1975) was used to determine nisin concentrations in milk and cheese. To extract nisin from cheese,

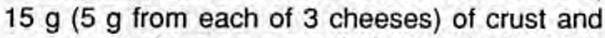
core were placed separately in $60 \mathrm{ml}$ of $0.02 \mathrm{~N}$ $\mathrm{HCl}$ and homogenized with a Waring blender for $2 \mathrm{~min}$. After $\mathrm{pH}$ adjustment to 2.0 , the suspension was heated for $5 \mathrm{~min}$ at $98^{\circ} \mathrm{C}$ to release nisin and centrifuged $\left(6000 \mathrm{~g}\right.$ for $10 \mathrm{~min}$ at $4^{\circ} \mathrm{C}$ ). The supernatants were used for the assay. Micrococcus luteus ATCC 10240 was used as the test-organism.

\section{pH determination}

The $\mathrm{pH}$ of milk was determined using a $\mathrm{pH}$ meter Knick (Portamess 654 Model) equipped with a combination glass electrode (Ingold). The $\mathrm{pH}$ at the surface and in the curd of cheeses was determined using a $\mathrm{pH}$-meter Metrohm $\mathrm{He}$ risau (Sofranie) equipped with a flat surface contact glass electrode.

\section{RESULTS AND DISCUSSION}

\section{Variations in cheese manufacture}

Variation between results of different experiments as well as within experiments occurred during the study (table I). In each experiment, milk fermentation was faster with the control starter than with the nisinproducing $\left(\mathrm{Nis}^{+}\right)$starter, regardless of the initial temperature of milk. Since $\mathrm{pH}$ was used to monitor the process, differences in rate of acidification resulted in delays at steps like cutting curd, hooping, turning, and so on, between control and experimental batches. Accordingly, temperatures at which these operations took place were not the same, those for control being higher than for experimental cheeses. Differences in time at cutting curd were observed until the first turn. Afterwards, they decreased rapidly, probably because $\mathrm{pH}$ was nearing its final value in both control and experimental cheeses.

Such differences in rate of milk acidification between the $\mathrm{Nis}^{+}$and the $\mathrm{Nis}^{-}$starters were not observed in a preliminary study in which a reference skim milk was used. The differences observed during cheese making may be attributed to variations in the nutrient value of milk, resulting in changes in the balance between $\mathrm{Prt}^{+}$and Prt cells during fermentation. This balance was shown to greatly affect the rate of milk acidification (Juillard, 1991).

As expected, with higher initial temperatures of milk (trial 2 and 3 ), acidification was faster, allowing earlier cutting and the following two steps. In trial 3 , cheese temperature at salting was notably higher than in the other experiments $\left(22.5-22.2^{\circ} \mathrm{C}\right.$ vs $\left.19.0^{\circ} \mathrm{C}\right)$.

\section{Evolution of lactococci and nisin concentration during manufacture and ripening of cheese}

An illustration of the behaviour of the $\mathrm{Nis}^{+}$ starter in milk and Camembert cheese is shown in figure 1 . Increase in population during the first $6 \mathrm{~h}$ is mainly caused by concentration of cells entrapped in curd and a slight increase due to growth. After the first day of manufacture, the numbers of lactococci began to decrease in cheese. This lack of viability may be characteristic trait of the strain used or of any $\mathrm{Nis}^{+}$lactococci, since in other studies, counts of Nislactococci were found to be rather stable (Martley, 1975; Richard, 1984).

Nisin production paralleled the growth of $L$ lactis. There was an increase of nisin concentration in the first $9 \mathrm{~h}$, nearing 700 $\mathrm{IU} / \mathrm{g}$. This increase was followed by a dramatic drop, between $24 \mathrm{~h}$ and 1 week of ageing. This observation is in agreement with that of Hurst (1966) who showed that 


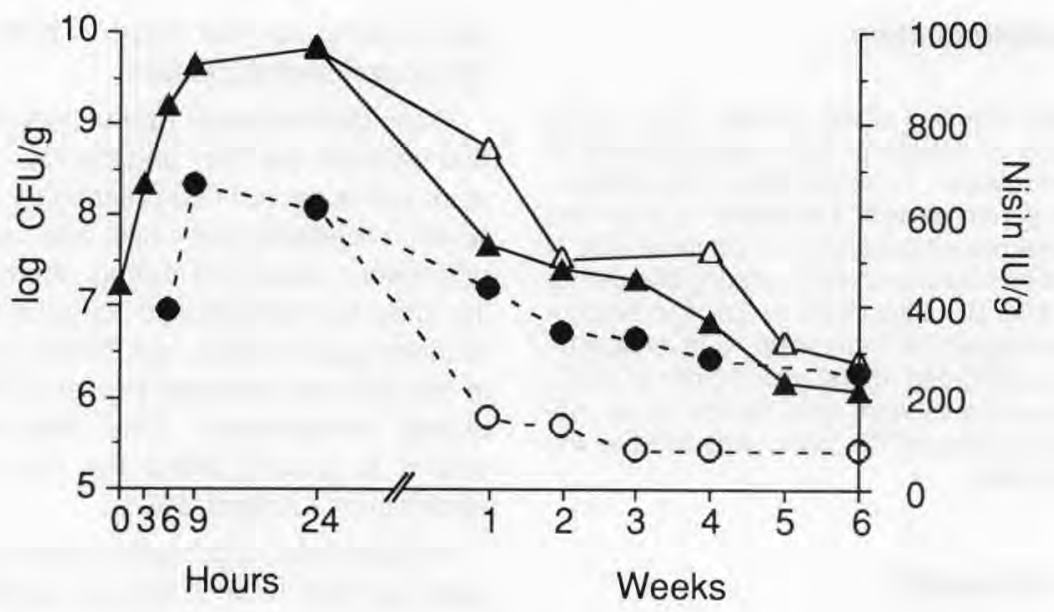

Fig 1. Behaviour of Lactococcus lactis subsp lactis $\operatorname{CNRZ} 150(\mathbf{\Delta}, \Delta)$ and concentration of nisin $(\bullet, 0)$ during manufacture and ripening of Camembert cheeses (results of trial 2). Each point represents the mean of triplicate determinations on 3 different batches of cheese. Solid symbols indicate the determinations in the curd of the cheeses, open symbols determinations on the crust of cheeses.

Évolution de Lactococcus lactis subsp lactis CNRZ $150(\mathbf{\Delta}, \Delta)$ et de la concentration en nisine $(\bullet, 0)$ pendant la fabrication et l'affinage des Camemberts (résultats de l'essai 2). Chaque point représente la moyenne de 3 déterminations sur des fromages de trois bassines différentes. Les symboles pleins représentent l'intérieur des fromages, les symboles ouverts, la surface.

in a culture medium, nisin was produced during the exponential phase of growth of the culture and that inactivation started just before the onset of the stationary phase of growth. According to this author and Ergorov et al (1982), this inactivation might be induced by an enzymatic system produced by the $\mathrm{Nis}^{+}$strains themselves. Thus, several phenomena may have occurred concurrently in the curd between 9 and $24 \mathrm{~h}$ : production of nisin and its concentration followed by a decrease due to enzymatic inactivation of the molecule and/or loss into whey. These facts probably explain why the nisin content of the curd was 2-3 times lower than that observed in milk by Jakubczyk et al (1973), Kalra and Dudani (1974), Oberman and Piatkiewicz (1978) and Ergorov (1980). Thereafter, the decrease was less rapid. It is worth mentioning that it was steeper in the crust than in the core of the cheese. At least two reasons might explain the decrease of nisin concentration in cheese during ripening. Firstly, as nisin is a polypeptide it is susceptible to the action of proteases (Heinemann and Williams, 1966; Phillips et al, 1983). In the case of Camembert cheese, the proteases are those released by the lysis of the lactic acid bacteria and additionally, those produced by mold in the crust. As protein breakdrown is more pronounced in the crust than in the interior of mold surface ripened cheeses, the decline of nisin concentration is consequently greater on the surface than in the core of the cheese. In addition, incomplete extraction of nisin due to binding to cheese components (fat and particular proteins) may also have occurred. This is suggested by the previous studies that showed poor recovery due to strong adsorption of nisin to meat proteins (Scott and Taylor, 1981; Bell 
and De Lacy, 1986; Chung et al, 1989) or binding to fat (Jones, 1974) or fat and proteins present in cheese spread (Somers and Taylor, 1987). Therefore, the nisin determinations in ripened cheese might represent only the unbound nisin and part of the bound molecules extracted by boiling cheese suspensions at $\mathrm{pH} 2.0$, the remainder being inactivated by proteolysis or irreversibly adsorbed onto fat or proteins.

\section{Evolution of $\mathrm{L}$ monocytogenes in milk and cheese}

\section{Comparison of media and cultures conditions}

Counts of $L$ monocytogenes from control and experimental cheeses on Oxford agar were close to those obtained on TSA-YE and BHIA (fig 2). The selective culture conditions used for the latter two media were effective in separating $L$ monocytogenes from the lactococci and mold: incubation at low temperature $\left(4^{\circ} \mathrm{C}\right)$ and anaerobiosis prevented growth of lactococci and mold, respectively. Nearly all the data points representing the numbers of Listeria were on the bisecting line, indicating that the two media gave similar results. However, two data points obviously underestimated Listeria counts on both TSAYE and BHIA. They correspond to bacteria in 1 week-old cheese made with $\mathrm{Nis}^{-}$ lactococci. This suggests that the selective conditions of culture (low temperature and/or anaerobiosis) could have had a greater inhibitory effect on cells injured by acidic conditions than the selective agents
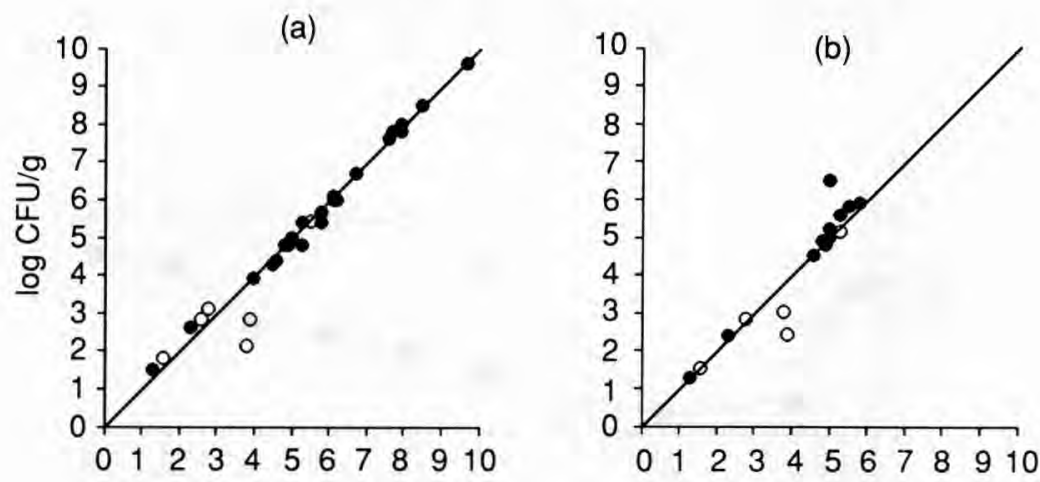

$\log \mathrm{CFU} / \mathrm{g}$ on Oxford Agar

Fig 2. Comparison of Listeria monocytogenes (strain V7) counts on Oxford and two non-selective media (results of trial 1, Nis- and Nis+ cheeses): (a) TSA-YE (Tryptic-Soy Agar + Yeast Extract) incubated 22 days at $4{ }^{\circ} \mathrm{C}$ in anaerobic conditions (Gaspak System, $\mathrm{H}_{2}+\mathrm{CO}_{2}$ ); (b) BHIA (Brain Heart Infusion Agar) incubated 28 days at $4{ }^{\circ} \mathrm{C}$ in long narrow tubes insuring anaerobic conditions (Raibaud's tubes)., 0 : bacteria in growth phase and in decline phase, respectively.

Comparaison du nombre de Listeria monocytogenes (souche V7) obtenu sur le milieu Oxford et sur 2 milieux ne contenant pas d'agents sélectifs (résultats de l'essai 1, fromages Nis et Nis') : (a) TSAYE ("Tryptic-Soy Agar + Yeast Extract”) incubé $22 j$ à $4{ }^{\circ} \mathrm{C}$ en conditions d'anaérobiose (Système Gaspak, $\mathrm{H}_{2}+\mathrm{CO}_{2}$ ). (b) BHIA ( «Brain Heart Infusion Agar») incubé $28 j$ à $4{ }^{\circ} \mathrm{C}$ en condition d'anaérobiose (tubes de Raibaud). $\bullet, 0$ : bactéries en phase de croissance et de déclin, respectivement. 
used in Oxford medium. If this was true we should have observed the same in the experimental cheese. Oxford Agar medium was found equal or superior to other selective media, like Modified McBride Agar (Northolt, 1989; Tiwari and Aldenrath, 1990). Moreover, Listeria colonies on Oxford Agar are easily recognizable within $24 \mathrm{~h}$ incubation due to the aesculin-ferric ammonium citrate indicator system. These reasons led us to select this medium for enumerating Listeria in cheese throughout the study.

\section{Evolution of $L$ monocytogenes counts and $\mathrm{pH}$ during manufacture and ripening of cheese}

Cheeses made with high levels of Listeria

No significant growth of Listeria was observed during the first $3 \mathrm{~h}$ of cheese making with either the $\mathrm{Nis}^{-}$or $\mathrm{Nis}^{+}$starter cultures and $10^{5}$ Listeria/ml in milk (fig 3). This observation is consistent with results obtained by Ryser and Marth (1987b) who made Camembert cheese, using the same strain of Listeria (V7). The absence of
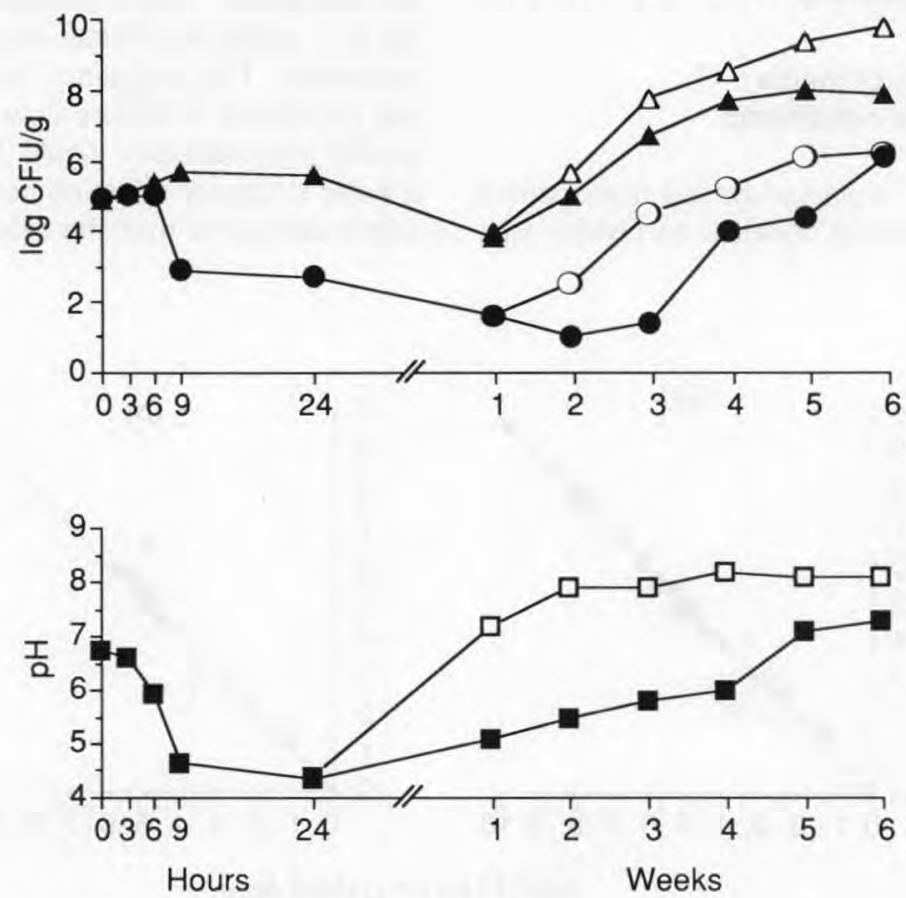

Fig 3. Behaviour of Listeria monocytogenes (strain V7) and pH in Camembert cheeses (results of trial 1, initial inoculum: $10^{5}$ Listeria/ml). $\mathbf{\Delta}, \Delta$ : cheese made with non nisin-producing starter; $\bullet, \bigcirc$ : cheese made with nisin-producing starter; $\mathbf{E}, \square$ : mean value of $\mathrm{pH}$ determinations in cheese made with non nisinproducing and nisin-producing Lactococcus lactis. Solid symbols indicate the determinations in the core of the cheese. Open symbols indicate the determinations in the crust of cheese.

Évolution de Listeria monocytogenes (souche V7) et du pH dans les Camemberts (résultats de l'essai 1 , inoculum initial : $10^{5} \mathrm{Listeria/ml)).} \mathbf{\Delta}, \Delta$ : Camembert fabriqué avec des levains lactiques non producteurs de nisine;, 0 : Camembert fabriqué avec des levains lactiques producteurs de nisine; $\square, \square$ : moyenne des $\mathrm{pH}$ mesurés à partir des fromages fabriqués avec des souches de Lactococcus lactis Nis- et Nis'. Les symboles pleins représentent l'intérieur du fromage, les symboles ouverts, la surface. 
growth may be explained by a particularly long lag phase for this strain. This is in agreement with Rosenow and Marth's results (1987) who recorded a $2 \mathrm{~h}$ lag phase when this strain was grown at $35^{\circ} \mathrm{C}$ in autoclaved skim milk.

Between 3 and $9 \mathrm{~h}$, the numbers of Listeria increased by $0.7 \mathrm{log} C F U / g$ in the control curd. This increase could be due to cell entrapment in curd, as was previously noted by Ryser and Marth (1987b). During the same period of time, in curd fermented by $\mathrm{Nis}^{+}$lactococci, there was at first no increase in Listeria population (from 3-6 h) followed by a dramatic decrease (by ca 2.0 $\log \mathrm{CFU} / \mathrm{g}$ ) between 6 and $9 \mathrm{~h}$. Undoubtedly this is the result of accumulated nisin and its bactericidal activity. There was no further significant change in Listeria counts in both the control and experimental cheeses, between $9 \mathrm{~h}$ and salting time (24 h).

In both, control and $\mathrm{Nis}^{+}$cheeses, there was a decrease of 1-2 log CFU/g between 1 and 7 days of ripening at $11^{\circ} \mathrm{C}$. This decrease occurred both in the crust and in the core to a similar extent. Ryser and Marth (1987b) observed a similar decrease during 24 days of ripening with 3 other strains of Listeria (Scott A, California, and Ohio) but not with V7. This might indicate the possible differences among Listeria relative to their competitive responses against different lactic starters.

The surviving Listeria reinitiated growth in the crust and core of control cheese and only in the crust of the $\mathrm{Nis}^{+}$cheese between 1 and 2 weeks of ageing while in the core of $\mathrm{Nis}^{+}$cheese, there was a further decrease of Listeria $(0.6 \log \mathrm{CFU} / \mathrm{g})$. This decrease of Listeria in the core of $\mathrm{Nis}^{+}$ cheese occurred at a similar $\mathrm{pH}$ to that noted during the decrease of Listeria in curd, but at a lower temperature $\left(11^{\circ} \mathrm{C}\right.$ vs 25 $\left.{ }^{\circ} \mathrm{C}\right)$. The increase of Listeria in the crust of
$\mathrm{Nis}^{+}$cheese after 1 week of ageing, similar to that in the crust of control cheese, was unexpected because $400 \mathrm{IU} / \mathrm{g}$ of nisin were still present. In fact, $200 \mathrm{IU} / \mathrm{ml}$ was shown to cause a $2 \log$ units decrease of Listeria in whole milk at $\mathrm{pH} 6.7$ (Williams and Tatini, personal communication). A small percentage of the total assayable ni$\sin$ (with acid extraction at $\mathrm{pH} 2.0$ and boiling) could be the only part available in the aqueous portion of the cheese. This availability of nisin is further influenced by the changing $\mathrm{pH}$ (increasing) which influences the solubility of nisin: solubility decreased from $57 \mathrm{mg} / \mathrm{ml}$ at $\mathrm{pH} 2.0$ to $1.5 \mathrm{mg} / \mathrm{ml}$ at $\mathrm{pH} 6.0$ and $0.25 \mathrm{mg} / \mathrm{ml}$ at $\mathrm{pH} 8.5$ (Liu and Hansen, 1990). An additional factor which might interfere with the activity of nisin is its adsorption to fat and proteins (Somers and Taylor, 1987) changing during ripening, in relation with the increase in $\mathrm{pH}$. The activity of nisin is further influenced by breakdown of the molecule by the mold growth in the crust.

After 4 weeks of ripening at $11^{\circ} \mathrm{C}$, $L$ monocytogenes seemed to have reached maximum populations both on the surface and in the core of cheese made with $\mathrm{Nis}^{-}$lactococci (ca $9.10^{9}$ and $1.10^{8}$ CFU/g, respectively). However, in a simulation of a temperature abuse on 6-weekold cheeses ( 2 days of incubation at $20^{\circ} \mathrm{C}$ ), Listeria counts increased by $0.6 \mathrm{log}$ $\mathrm{CFU} / \mathrm{g}$ in the core (4-fold increase in counts) whereas no change in counts was observed on the surface. On the other hand, the same temperature abuse, when applied to cheese made with $\mathrm{Nis}^{+}$lactococ$\mathrm{ci}$, gave counts increased by $0.4 \mathrm{log} \mathrm{CFU} / \mathrm{g}$ in the core and 1.3 in the crust, ie more than in control cheese. Two factors may explain this apparent paradox: lower initial counts in experimental than in control cheese, allowing more possibility for growth, associated with more pronounced inactivation of nisin at higher temperature. 
Variation in behaviour of $\mathrm{L}$ monocytogenes during manufacture and ripening of cheeses The general behaviour of Listeria monocytogenes in Camembert cheese hitherto described for trial 1 was also observed in other experiments with some variations (table II). Listeria numbers at time of salting increased by $0.8 \log$ CFU/g (average of 2 experiments) in control cheese. This increase is of the same order of magnitude as that observed by Ryser and Marth (1987b) for the same kind of cheese. Dur- ing the same period of time, Listeria counts decreased by 1 to $2 \log \mathrm{CFU} / \mathrm{g}$ in the experimental cheese, depending on the experiment. There is no clear relationship between the variations in cheese manufacture and the behaviour of $L$ monocytogenes in curd. For instance, milk acidification was slower in trial 1 than in the other trials, but Listeria decrease was faster.

During the first week of cheese ripening, there was no difference in the level of decrease of Listeria between control and $\mathrm{Nis}^{+}$

Table II. Fate of Listeria monocytogenes (strain V7) in Camembert cheese made with milk containing non nisin-producing $\left(\mathrm{Nis}^{-}\right)$or nisin-producing $\left(\mathrm{Nis}^{+}\right)$strains of Lactococcus lactis subsp lactis and inoculated with $10^{5} \mathrm{CFU} / \mathrm{ml}$ of Listeria. The variables in italic represent the average value of the variables printed above them.

Comportement de Listeria monocytogenes (souche V7) dans du Camembert fabriqué avec du lait contenant des souches de Lactococcus lactis subsp lactis non-productrices de nisine (Nis ${ }^{-}$) ou productrices de nisine $\left(\mathrm{Nis}^{+}\right)$et $10^{5} \mathrm{CFU} / \mathrm{ml}$ Listeria. Les variables en italique représentent la moyenne des variables situées au-dessus.

\begin{tabular}{|c|c|c|c|c|c|c|c|c|c|c|}
\hline \multirow{3}{*}{$\begin{array}{l}\text { Period } \\
\text { of time }\end{array}$} & & \multicolumn{9}{|c|}{ Changes in counts (log CFU/g) } \\
\hline & & \multicolumn{4}{|c|}{ Nis starters } & \multicolumn{5}{|c|}{$\mathrm{Nis}^{+}$starters } \\
\hline & & \multirow{2}{*}{$\begin{array}{r}\text { Trial } 1 \\
+0.8\end{array}$} & \multirow{2}{*}{$\begin{array}{l}\text { Trial } 3 \\
+0.9\end{array}$} & \multicolumn{2}{|c|}{ Mean SD } & \multirow{2}{*}{$\begin{array}{l}\text { Trial } 1 \\
-2.0\end{array}$} & \multirow{2}{*}{$\begin{array}{l}\text { Trial } 2 \\
-0.9\end{array}$} & \multirow{2}{*}{$\begin{array}{c}\text { Trial } 3 \\
-0.3\end{array}$} & \multicolumn{2}{|c|}{ Mean SD } \\
\hline $0-9 \mathrm{~h}$ & & & & +0.85 & 0.07 & & & & -1.07 & 0.86 \\
\hline $9-24 \mathrm{~h}$ & & -0.1 & 0 & -0.05 & 0.07 & -0.2 & -0.2 & -1.1 & -0.50 & 0.52 \\
\hline $0-24 \mathrm{~h}$ & & +0.7 & +0.9 & +0.80 & 0.14 & -2.2 & -1.1 & -1.4 & -1.57 & 0.57 \\
\hline \multirow{2}{*}{\multicolumn{2}{|c|}{$\begin{array}{r}24 \text { h-1 week core } \\
\text { crust }\end{array}$}} & -1.8 & -1.5 & -1.65 & 0.21 & -1.1 & -1.8 & -2.0 & -1.63 & 0.47 \\
\hline & & -1.7 & -1.8 & -1.75 & 0.07 & -1.1 & -1.9 & -2.3 & -1.76 & 0.61 \\
\hline 0-1 week & & -1.05 & -0.75 & -0.90 & 0.21 & -3.30 & -2.95 & -3.55 & -3.27 & 0.30 \\
\hline \multirow[t]{2}{*}{$1-2$ weeks } & core & +1.2 & nd & & & -0.6 & -1.0 & nd & -0.80 & 0.28 \\
\hline & crust & +1.7 & nd & & & +0.9 & -0.2 & nd & & \\
\hline \multirow[t]{2}{*}{$2-5$ weeks } & core & +2.9 & nd & & & +4.7 & +5.2 & nd & +4.95 & 0.35 \\
\hline & crust & +4.2 & nd & & & +3.6 & $>+3.7$ & nd & & \\
\hline \multirow[t]{2}{*}{$1-5$ weeks } & core & +4.1 & & & & +4.1 & +4.2 & & +4.15 & 0.07 \\
\hline & crust & +5.9 & & & & +4.5 & $>+3.5$ & & & \\
\hline
\end{tabular}

SD: Standard deviation; nd: not determined.

SD : écart type; nd: non déterminé. 
cheeses or between core and crust. As $\mathrm{pH}$ of the interior of cheese was below 5 , this confirms earlier studies showing that nisin was less effective or ineffective at a $\mathrm{pH}$ lower than 5.0 (Waites and Odgen, 1987; Monticello and O'Connor, 1990; Radler, 1990). However, some authors (using different systems) found that nisin was more effective at a low $\mathrm{pH}$ (Rayman et al, 1983; Mohamed et al, 1984; Sahl et al, 1987; Bekerroum and Sandine, 1988). For example, Mohamed et al (1984) found that the amount of nisin to completely inhibit Listeria was 16 -fold lower at $\mathrm{pH} 5.5$ than at $\mathrm{pH}$ 7.4. The decrease of Listeria in the crust of $\mathrm{Nis}^{-}$as well as $\mathrm{Nis}^{+}$cheeses, although the $\mathrm{pH}$ was rising, is more difficult to explain. It could be due to the combined effect of salt and low temperature on Listeria previously impaired by the acidic conditions. The absence of an extra inhibitory effect of nisin may be due to two factors: firstly, salt was shown to antagonize the action of nisin by interfering with nisin adsorption to bacteria cells (Bell and De Lacy, 1985); moreover, Mohamed et al (1984) showed that sensitivity of bacteria to nisin diminished when the temperature of incubation decreased. Nevertheless, an overall decrease of Listeria count of $\mathrm{ca} 1.0 \mathrm{log} \mathrm{CFU} / \mathrm{g}$ in the control and $3.3 \mathrm{log} \mathrm{CFU} / \mathrm{g}$ in the $\mathrm{Nis}^{+}$cheese was obtained from milk to cheese aged 1 week (table II).

During the second week, there was a further decrease in the core and only a small increase on the surface of $\mathrm{Nis}^{+}$ cheese, whereas an increase of 1.2-1.7 log unit was observed in both the core and crust of control cheese. This continued decrease or delay in growth of Listeria in the core during the second week of ripening of $\mathrm{Nis}^{+}$cheeses could be due to the greater effectiveness of the remaining nisin as $\mathrm{pH}$ increased to values above 6.0-6.5, allowing greater nisin adsorption on the cell surface (Hurst, 1981) and/or better efficiency (Waites and Ogden, 1987; Monticelio and
O'Connor, 1990). Afterwards, Listeria was able to grow even in the presence of 250 $300 \mathrm{IU} / \mathrm{g}$ of nisin, probably because most of the molecules were preferably adsorbed onto fat and proteins resulting from extensive ripening of the cheese surface. During weeks $1-5$, there was an overall increase of ca $4 \log$ CFU/g in the core of the cheese. regardless of the presence of nisin.

The total counts (calculated results) in $\mathrm{Nis}^{+}$cheese at the end of ripening were $\mathrm{ca}$ 2.5 log units lower than in control ones, ie the difference was approximately the same as that observed after 2 weeks.

In cheese made from milk containing $10^{3}$ Listeria/ml and $\mathrm{Nis}^{+}$lactococci, counts of $L$ monocytogenes were close to the predicted numbers (on the basis of data from $10^{5}$ level) during the manufacture and then below the limit of detection by direct plating (ie less than 10/g), as expected. However, at the end of the ripening period ( 5 weeks), the counts were largely below the predicted numbers: less than $10 \mathrm{CFU} / \mathrm{g}$ in both core and crust instead of the expected $10^{4}$ and $10^{3}$, respectively. This suggests that nisin was more efficient when less Listeria were present in milk as postulated by Mohamed et al (1984) and Monticello and O'Connor (1990).

\section{Cheeses made with low levels of Listeria}

With an initial level of $10^{1} \mathrm{CFU} / \mathrm{ml}$ in milk used for making cheese with the Nis- starter, Listeria counts were, during the first 2 weeks, under the limit of detection by direct plating on Oxford agar, ie less than 10 Listeria/g. Afterwards, the bacteria resumed their growth and reached $\mathrm{ca} 10^{5}$ $\mathrm{CFU} / \mathrm{g}$ in rind and $10^{3}$ in core of 6-week cheeses. In contrast, the counts in $\mathrm{Nis}^{+}$ cheeses were under $10 / g$ throughout the ripening period.

$L$ monocytogenes were not detected in $25 \mathrm{~g}$ of 1 or 2-week old cheeses made with Nis ${ }^{-} L$ lactis, although colonies of this bac- 
terium were present on Oxford agar. Assuming that the enrichment broth was too inhibitory for Listeria sublethally injured by acidic conditions, the following modifications of the selective enrichment broth (SEB) were tested: i) omission of acriflavin and addition of an active phage to destroy the lactococci, ii) addition to SEB of $1.5 \%$ lithium chloride to inhibit the lactococci, iii) use of a buffer (HEPES $250 \mathrm{mmol} / \mathrm{l}$ (Sigma)) to prevent $\mathrm{pH}$ drop, iv) combination of i) and iii). In Nis- cheeses aged for 1 week, Listeria were detected after 1 day of incubation in all modified SEB, and in 2week old cheeses, in all samples with modification (ii). This confirms the problem of recovery and detection of low densities of injured Listeria cells in cheese (Northolt, 1989). However, Listeria were never detected in $\mathrm{Nis}^{+}$cheeses aged for 1 or 2 weeks, regardless of the enrichment broth used, even after 2 days of incubation. Three reasons could be put forward to explain these results: firstly, the bacteria in $\mathrm{Nis}^{+}$cheeses were in worse physiological conditions than those in the control cheese and therefore, were killed during incubation of the enrichment broth secondly, the numbers of cells were too low to be detected after only 2 days of incubation; thirdly, the cell density was too low to allow a representative sampling. In fact, there were no Listeria detected in five $25-\mathrm{g}$ test aliquots of cheese (a wedge of ca $8 \mathrm{~g}$ of cheese was taken from 3 different cheese wheels to make a comingled sample). The latter situation of low densities of Listeria would be consistent with the following view on the fate of Listeria during cheesemaking and ripening: if the initial count of Listeria is low, say $10 / \mathrm{ml}$, there would only be a few surviving cells in $\mathrm{Nis}^{+}$cheese aged for 1 or 2 weeks, that is less than $10^{-2} / \mathrm{g}(10)$ $\mathrm{kg}$ ) due to a reduction of at least $3 \mathrm{log}$ units in the first 2 weeks (as seen in this study), and probably less than 0.25 Listeria per $25 \mathrm{~g}$ sample. Thus, the probability of having a Listeria-free sample is very high together with the problem of recovery of few injured Listeria present with a tremendous number of lactococci. Lactococci should be inhibited in the enrichment broth to avoid any production of acid and/or ni$\sin$. It is not known at present if the selective agents chosen for the enrichment broth are totally harmless for injured Listeria.

Despite the points mentioned above, the data presented here have clearly demonstrated the usefulness of $\mathrm{Nis}^{+}$lactococci in killing $L$ monocytogenes in Camembert cheese ( 3 log units decrease based on direct enumeration). Data have also demonstrated their greater effectiveness, especially with lower levels of initial Listeria (10/ $\mathrm{ml}$ ) in cheese milk to result in the absence of Listeria in $25 \mathrm{~g}$ of cheese even after aging for 6 weeks. This, however, may not offer absolute assurance of safety because a single cell in the crust and core may result in a colony of $10^{7}$ and $10^{5}$ cells in the crust and core, respectively.

\section{CONCLUSIONS}

Two main conclusions can be drawn from the present study. The first is that nisinproducing Lactococcus lactis ( $\mathrm{Pr}^{+}$and $\mathrm{Prt}$ strains combination) was found to be suitable as a starter for manufacture of Camembert cheese by providing the appropriate $\mathrm{pH}$ at cutting, hooping, turning and finished cheese stages and that $\mathrm{Nis}^{+}$starter are able to control $L$ monocytogenes during cheese making. The effectiveness of nisin was particularly great when low levels of Listeria $\left(10^{3}\right.$ and $\left.10^{1} \mathrm{CFU} / \mathrm{ml}\right)$ were present in milk. It could be useful to prevent a possible post-pasteurization contamination of milk cheese or curd, and for making cheese from raw milk, provided there were low initial numbers of Listeria, 
say less than 10 per $\mathrm{ml}$. The system can be improved by selecting faster growing strains, developing "super nisin-producers" and/or adding extra nisin in milk so that enough nisin would be present when the $\mathrm{pH}$ was between 6.8 and 6.0 and the temperature was still around $30^{\circ} \mathrm{C}$ for maximum bactericidal effect.

The second conclusion is that the nisin system has limits in preventing regrowth of survival Listeria during Camembert cheese ripening, as cheese $\mathrm{pH}$ increases. The sam, would likely be true for other bacteriocins as these compounds by definition, are proteins, and are susceptible to proteolytic degradation. Presently, improvement of the nisin system seems to be the simplest way to obviate this problem.

Among the possible side-effects of using nisin-producing starters, the inhibition of the bacteria involved in flavor development and the emergence in the cheese factory environment of nisin-resistant (Nis $\left.{ }^{\circledR}\right)$ strains of $L$ monocytogenes must be considered as the most serious. The former could be overcome by selecting $\mathrm{Nis}^{(\mathbb{( B )}}$ strains of appropriate organisms. The second one could be minimized by controlling the level of $L$ monocytogenes in the dairy environment.

The problem of detecting a few sublethally injured Listeria in the presence of a tremendously dominant bacterial flora could be made more complicated by the use of bacteriocin-producing starters. The addition to the enrichment media of compounds adsorbing the bacteriocins or destroying them could be solutions to solve this problem.

If these findings concerning the destruction of $L$ monocytogenes V 7 can be confirmed with other Listeria strains and that the use of $\mathrm{Nis}^{+} L$ lactis has no effect on the flavor development, the use of $\mathrm{Nis}^{+}$lactococci starter would be an effective, simple and economic means to control Listeria in cheese made from raw milk. Good manufacturing practices are also important to minimize the initial contamination levels of Listeria and other psychrotrophic contaminants.

\section{ACKNOWLEDGMENTS}

The assistance of $G$ Pittel and L Vassal, INRA, Jouy-en-Josas, for cheese manufacture is gratefully acknowledged.

\section{REFERENCES}

Asperger H, Url B, Brandl E (1989) Interactions between Listeria and the ripening flora of cheese. Neth Milk Dairy J 43, 287-298

Bell RG, De Lacy KM (1985) The effect of nisinsodium chloride interactions on the outgrowth of Bacillus licheniformis. J Appl Bacteriol 59, 127-132

Bell RG, De Lacy KM (1986) Factors influencing the determination of nisin in meat products. J Food Technol 21, 1-7

Benkerroum N, Sandine WE (1988) Inhibitory action of nisin against Listeria monocytogenes. J Dairy Sci 71, 3237-3245

Carminati D, Giraffa G, Bossi MG (1989) Bacteriocin-like inhibitors of Streptococcus lactis against Listeria monocytogenes. J Food Prot 52, 614-617

Chung KT, Dickson JS, Crouse JD (1989) Effects of nisin on growth of bacteria attached to meat. Appl Environ Microbiol 55, 1329-1333

Curtis GDW, Mitchell LRG, King AF, Griffin EJ (1989) A selective differential medium for the isolation of Listeria monocytogenes. Lett Appl Microbiol 8, 95-98

Ergorov NS, Baranova IP, Kozlova Yu I, Grushina VA, Goliko-Va TI, Volkov AG, Isai PP, Isai El, Sidovenko AT (1980) Optimization of nutrient medium for nisin producing Streptococcus lactis strain MGU. Biologischeskie 7, 87-89

Ergorov NS, Grushing VA, Kozlova Yu I, Baranova IP, Polin AN (1982) Nisin inactivation in culture in the nisin-producing strain MGU of Streptococcus lactis. Antibiotikov 27, 757-761 
Fowler GG, Jarvis B, Tramer J (1975) The assay of nisin in foods. In: Some Methods for Microbiological Assay (Board RG, Lovelock DW, eds) Academic Press, London

Harris LJ, Daeschel MA, Stiles ME, Klaenhammer TR (1989) Antimicrobial activity of lactic acid bacteria against Listeria monocytogenes. J Food Prot 52, 384-387

Heinmann B, Williams R (1966) Inactivation of nisin by pancreatine. J Dairy Sci 49, 312-315

Hirsch A, Grinsted E, Chapman HR, Mattick ATR (1951) A note on the inhibition of an anaerobic sporeformer in Swiss-type cheese by a nisin-producing Streptococcus. I Dairy Res $18,205-206$

Huggins AR, Sandine WE (1984) Differential of fast and slow milk-coagulating isolates in strains of lactic streptococci. J Dairy Sci 67, 1674-1679

Hurst A (1966) Biosynthesis of the antibiotic nisin and other basic peptides by Streptococcus lactis grown in batch culture. J Gen Microbiol 45, 503-513

Hurst A (1981) Nisin. Adv Appl Microbiol 27, 85123

ISO (1989) Lait et produits laitiers. Recherche et dénombrement de Listeria monocytogenes. Bull, 307

Jakubczyk E, Lipinska E, Szadkowska M, Lipniewska D (1973) Selection of Streptococcus lactis strains with enhanced nisin production. Roczniki Inst Przemyslu Mleczarsklego 15, 97-106

Jones LW (1974) Effect of butterfat on inhibition of Staphylococcus aureus by nisin. Can J Microbiol 20, 1257-1260

Juillard V (1991) Interactions directes et indirectes entre souches protéolytiques et variants isogéniques non protéolytiques de Lactococcus lactis au cours de leur croissance dans le lait. Thesis, Univ. Paris VII

Kalra MS, Dudani AT (1974) Effect of calcium carbonate on nisin production in a milk culture. Indian J Dairy Sci 27, 146-148

Klaenhammer TR (1988) Bacteriocins of lactic acid bacteria. Biochimie 70, 337-349

Lipinska E (1977) Nisin and its application. In: Antimicrobials and Antibiosis in Agriculture (Woodbine M, ed) Butterworths, London

Liu W, Hansen JN (1990) Some chemical and physical properties of nisin, a small-protein antibiotic produced by Lactococcus lactis. Appl Environ Microbiol 56, 2551-2558

Martley FG (1975) Comportement et rôle des streptocoques lactiques du levain en fabrication de Camembert. Lait 545, 310-323

Mohamed GEE, Seaman A, Woodbine M (1984) Food antibiotic nisin: comparative effects on Erysipelothrix and Listeria. In: Antimicrobials and Antibiosis in Agriculture (Woodbine M, ed) Butterworths, London

Monticello DJ, O'Connor D (1990) Lysis of Listeria monocytogenes by nisin. In: Foodborne Listeriosis (Miller AJ, Smith JL, Somkuti GA, eds) Academic Press, London

Northolt MD (1989) Recovery of Listeria monocytogenes from dairy products using the TNCB-TNCA method and the draft IDF methods. Neth Milk Dairy J 43, 299-310

Oberman H, Piatkiewicz A (1978) Improvement of nisin productivity in lactic acid streptococci. XX Int Dairy Congr, E, 508-510

Papageorgiou DK, Marth EH (1989) Fate of Listeria monocytogenes during the manufacture and ripening of blue cheese. J Food Prot 52, 459-465

Phillips JD, Griffiths MW, Muir DD (1983) Effect of nisin on the shelf-life of pasteurized double cream. J Soc Dairy Technol 36, 17-21

Radler F (1990) Possible use of nisin in winemaking. I. Action of nisin against lactic acid bacteria and wine yeast in solid and liquid media. Am J Enol Vitic 41, 1-6

Rayman K, Malik M, Hurst A (1983) Failure of nisin to inhibit outgrowth of Clostridium botulinum in a model meat system. Appl Environ Microbiol 46, 1450-1452

Richard J (1984) Évolution de la flore microbienne à la surface des Camemberts fabriqués avec du lait cru. Lait 64, 496-520

Rosenow EM, Marth EH (1987) Growth of Listeria monocytogenes in skim, whole, and chocolate milk, and in whipping cream during incubation at $4,8,13,21$ and $35^{\circ} \mathrm{C}$. J Food Prot 50, 452-459

Ryser ET, Marth EH (1987a) Behavior of Listeria monocytogenes during the manufacture and ripening of cheddar cheese. $J$ Food Prot $50,7-13$

Ryser ET, Marth EH (1987b) Fate of Listeria monocytogenes during the manufacture and ripening of Camembert cheese. J Food Prot $50,372-378$ 
Sahl HG, Kordel M, Benz R (1987) Voltagedependent depolarization of bacterial membranes and artificial lipid bilayers by the peptide antibiotic nisin. Arch Microbiol 149, 120124

Schillinger U (1990) Bacteriocins of lactic acid bacteria. In: Biotechnology and Food Safety (Bills DD, Kung SD, eds) ButterworthsHeinmann, Boston

Scott VN, Taylor SL (1981) Effect of nisin on the outgrowth of Clostridium botulinum spores. J Food Sci 46, 117-126

Somers EB, Taylor SL (1987) Antibotulinal effectiveness of nisin in pasteurized process cheese spreads. J Food Prot 50, 842-848

Spelhaug SR, Harlander SK (1989) Inhibition of foodborne bacterial pathogens by bacte- riocins from Lactococcus lactis and Pediococcus pentosaceous. J Food Prot 52, 856862

Tagg JR, Dajani AS, Wannamaker LW (1976) Bacteriocins of Gram-positive bacteria. Bacteriol Rev 40, 722-756

Tiwari NP, Aldenrath SG (1990) Isolation of Listeria monocytogenes from food products on four selective plating media. J Food Prot 53, 382-385

Waites MJ, Ogden K (1987) The estimation of nisin using ATP-bioluminometry. $J$ Inst Brew 93, 30-32

Yousef AE, Marth EH (1988) Behavior of Listeria monocytogenes during the manufacture and storage of Colby cheese. J Food Prot 51 , 12-15 